\title{
Permeation Resistance of Sawdust Ash Blended Cement Laterized Concrete
}

\author{
Folagbade, S.O. ${ }^{*}$ and Aluko, $0 .^{2}$
}

\begin{abstract}
This paper compared the initial surface absorption of conventional concrete and laterized concrete containing Portland cement (PC) and sawdust ash (SDA). Laterized concrete was produced at laterite contents of 15 and $30 \%$ as partial replacement for sand and SDA contents of 10 and $20 \%$ as partial replacement for PC. Compressive strengths at 28 days and initial surface absorption after 10 minutes (ISA-10) at 28, 60 and 90 days were determined at the water/cement ratios of $0.35,0.50$ and 0.65 and assessed at equal 28-day strengths of 25-35 $\mathrm{N} / \mathrm{mm}^{2}$. At equal water/cement ratios, compressive strength reduced and ISA-10 increased with increasing content of laterite and SDA. On the other hand, compressive strength and resistance to surface absorption of the blended cement laterized concretes increased with increasing curing age. At equal strengths, all the blended cement laterized concretes have better resistance to surface absorption than the conventional PC concrete.
\end{abstract}

Keywords: Absorption; blended cement; laterized concrete; permeation; sawdust ash.

\section{Introduction}

Concrete is a widely used construction material. The need to prevent the depletion of non-renewable materials and make concrete construction sustainable led to the replacement of the constituent materials of concrete with alternative ones. For example, the partial replacement of sand with laterite resulted in laterized concrete [1-7]. Hence, the use of laterized concrete will reduce the demand on sand and possibly reduce the cost of concrete where laterite is abundant and cheaper than sand. Concrete is expected to be properly proportioned and placed to ensure it achieves the expected strength and durability performance. Since laterite is characterized by higher content of fine particles than natural sand, laterized concrete would require higher content of water to achieve equal consistence with conventional concrete [2,3.8]. Nevertheless, the study by Falade [3] has shown that laterized concrete could still be designed to have good workability and ensure that it is properly placed. Also, the higher content of fine particles in laterite would result in higher specific surface and higher quantity of cement needed to properly coat the soil particles and ensure adequate hydration reaction within the matrix of the concrete.

\footnotetext{
${ }^{1}$ Department of Building, Obafemi Awolowo University, Ile-Ife, NIGERIA.

${ }^{2}$ Cartil Construction Generali Nigeria Limited, Ibadan, NIGERIA.

*Corresponding author; email: samuelfolagbade@yahoo.com
}

Note: Discussion is expected before November, $1^{\text {st }} 2019$, and will be published in the "Civil Engineering Dimension", volume 22, number 1, March 2020.

Received 17 July 2019; revised 11 September 2019; accepted 20 September 2019.
Hence, the compressive, tensile and flexural strengths of laterized concrete decreased with increasing content of laterite [4 5]. Nonetheless, if laterite is adequately proportioned and properly cured, laterized concrete would have good strength properties [4-11], good performance in aggressive environment [12-15] and good resistance against sorption [5-11]. However, to ensure good results, laterite content of concrete should be limited to about $20-50 \%$ of the total fine aggregate content $[2-4,5,8$ $11,16]$.

In order to make concrete more sustainable, the use of pozzolans has been supported by cement and concrete standards like BS EN 197-1 [17] and BS EN 206-1 [18]. Hence, attempts have been made to partially replace the Portland cement content of laterized concrete with pozzolanic materials such as fly ash [19,20], cassava peels ash [21] and volcanic ash [22,23], among others. Pozzolans have intrinsic hydraulicity and while they are characterized by low early-age strength development, their continuous pozzolanic reaction with age would result in concrete with high ultimate strength comparable with that of Portland cement concrete at later ages [24]. Hence, pozzolanic cements would be good for mass concrete or concrete works in hot weather, where high rate of strength development could lead to cracking. In addition to the pozzolanic reaction, the pozzolans, by virtue of their sizes and shapes and better packing density, also have the ability to refine the microstructure and improve the durability of concrete [24].

Sawdust is a waste generated in sawmills in large quantity over the world. Hence, the use of Sawdust Ash (SDA) in concrete would provide a means of 
solving the disposal problem of sawdust. As partial replacement for Portland cement, SDA would reduce the performance of concrete at early ages; however, the delayed setting times would lead to improved performance of concrete in hot weather [25]. Also, due to the continuous pozzolanic reaction with increasing age, SDA would contribute to later-age strength development of concrete [26-29] and resistance of concrete to water absorption [30] and sorption [5]. Also, since the manufacture of SDA would require lower calcination temperature than that of Portland cement clinker, SDA blended cement concrete would be cheaper and more environmentally friendly than Portland cement concrete.

From the foregoing, the combination of SDA and laterite as partial replacements for Portland cement and sand contents of concrete respectively would make concrete cheaper, more environmentally compatible and possibly more durable than the conventional concrete where laterite is abundant. Hence, in order to provide more information on the durability of SDA blended cement laterized concrete, this paper investigated the initial surface absorption after 10 minutes (ISA-10) of this concrete, at different water/cement ratios and 28-day compressive strengths, with a view to providing more information on its permeation resistance and suitability for construction. The initial surface absorption after 10 minutes could be used to sufficiently assess the ability of concrete to provide protection for its embedded reinforcing steel [31] and, possibly, wall finishes.

\section{Materials and Methods}

The experimental materials were ordinary Portland cement (PC) and calcined sawdust ash (SDA) as cements, sand and laterite as fine aggregates and granite chippings as coarse aggregates. Sawdust was calcined in a furnace maintained at $500^{\circ} \mathrm{C}$ for about 24 hours. The temperature of the furnace was monitored with the aid of a thermocouple. The oxide compositions of PC and SDA, determined by X-Ray Fluorescence (XRF), are presented in Table 1. The properties of the aggregates are presented in Table 2 and the grading curves of the aggregates are presented in Figure 1. Concrete was produced at 10 and $20 \%$ contents of SDA as partial replacement for PC, and 15 and $30 \%$ contents of laterite as partial replacement for sand. Concrete design was based on the Building Research Establishment approach [32] at a free water content of $210 \mathrm{~kg} / \mathrm{m}^{3}$ and water/ cement ratios of $0.35,0.50$ and 0.65 . To ensure equal consistence with increasing content of laterite [3], Mapefluid N200 conforming to EN 934-2 [33] was used as superplasticiser to achieve a consistence level of S2 defined by a nominal slump of 50-90 mm [18].
Table 1. Properties of Portland Cement and Sawdust Ash

\begin{tabular}{lcc}
\hline \multicolumn{1}{c}{ Elemental Oxide (\%) } & OPC & SDA \\
\hline $\mathrm{SiO}_{2}$ & 16.82 & 62.96 \\
$\mathrm{Al}_{2} \mathrm{O}_{3}$ & 4.35 & 8.29 \\
$\mathrm{Fe}_{2} \mathrm{O}_{3}$ & 2.43 & 3.85 \\
$\mathrm{CaO}$ & 60.39 & 9.53 \\
$\mathrm{MgO}$ & 1.43 & 5.48 \\
$\mathrm{SO}_{3}$ & 1.64 & 0.68 \\
$\mathrm{~K}_{2} \mathrm{O}$ & 0.16 & 0.15 \\
$\mathrm{Na}_{2} \mathrm{O}$ & 0.02 & 0.06 \\
$\mathrm{MnO}$ & 0.04 & 0.01 \\
$\mathrm{P}_{2} \mathrm{O}_{5}$ & 0.21 & 0.48 \\
$\mathrm{TiO}_{2}$ & 0.24 & 0.00 \\
$\mathrm{LOI}^{\mathrm{AR}}$ & 9.84 & 4.85 \\
$\mathrm{Free}_{\mathrm{Lime}}$ & 1.67 & 14.20 \\
$\mathrm{SiO}_{2}+\mathrm{Al}_{2} \mathrm{O}_{3}+\mathrm{Fe}_{2} \mathrm{O}_{3}$ & 0.36 & 0.00 \\
\end{tabular}

Table 2. Properties of Aggregates

\begin{tabular}{lccc}
\hline \multirow{2}{*}{ Properties } & \multicolumn{2}{c}{ Fine aggregates } & $\begin{array}{c}\text { Coarse aggregates } \\
\text { (Granite) }\end{array}$ \\
\cline { 2 - 3 } & Laterite & Sand & 6.95 \\
Fineness modulus & 3.03 & 3.12 & 1.55 \\
$\begin{array}{l}\text { Coefficient of } \\
\text { uniformity }\end{array}$ & 5.23 & 3.24 & 0.90 \\
$\begin{array}{l}\text { Coefficient of } \\
\text { curvature }\end{array}$ & 0.99 & 0.96 & \\
$\begin{array}{l}\text { Specific gravity } \\
\text { Moisture content, \% }\end{array}$ & 2.53 & 2.65 & 2.70 \\
Absorption, \% & 8.15 & 5.17 & 0.88 \\
$\begin{array}{l}\text { Liquid limit, \% } \\
\text { Plastic limit, \% }\end{array}$ & 37.0 & - & 1.58 \\
Plasticity index, \% & 17.0 & - & - \\
\hline
\end{tabular}

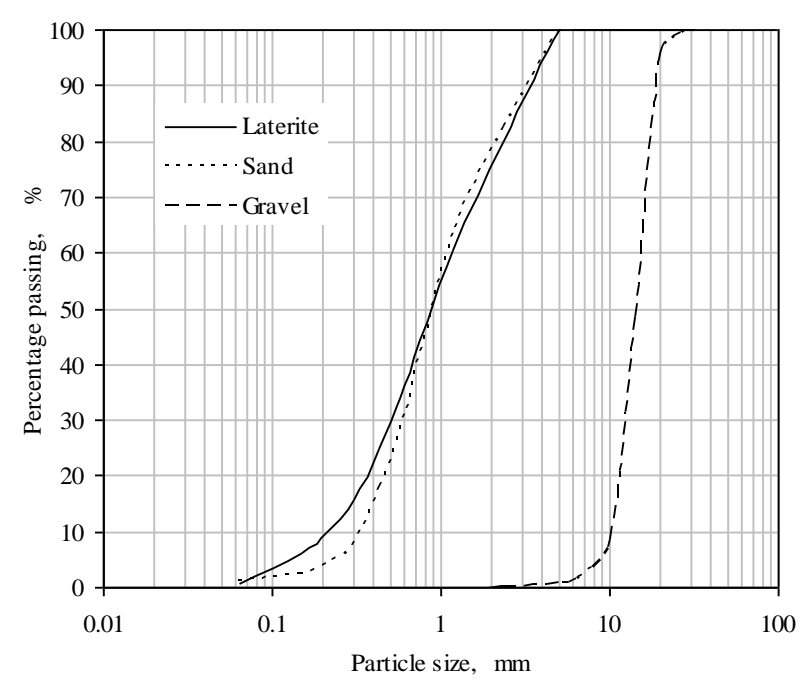

Figure 1. Particle Size Distribution of Aggregates

Concrete was prepared in accordance with BS EN 12390-2 [34] with potable water conforming to BS EN 1008 [35], cast, covered with polythene for about 24 hours, demoulded and cured in water. Compressive strength was determined in accordance with BS EN 12390-3 [36] using $100 \mathrm{~mm}$ cubes at 28 days. The initial surface absorption after 10 minutes (ISA10) at 28,60 and 90 days were obtained in accordance with BS 1881-208 [31] using $150 \mathrm{~mm}$ concrete 
cubes oven-dried to constant mass at $105 \pm 5^{\circ} \mathrm{C}$. The specimens were cooled to room temperature in a desiccator and subjected to a pressure of $200 \mathrm{~mm}$ head of water as shown in Figure 2. The tap on the initial surface absorption equipment was turned off after 10 minutes to remove the applied water head, and the average distance moved by water along the capillary tube in a minute was obtained. The ISA-10 values of the specimens were obtained using Equation 1.

ISA- $10=\mathrm{N}_{10} \times \mathrm{C}_{\mathrm{f}}$

where

ISA-10 = Initial surface absorption 10 minutes after water first touched the surface of concrete.

$\mathrm{N}_{10}=$ Number of scale divisions moved, in a minute, 10 minutes after water first touched the surface of concrete.

$\mathrm{C}_{\mathrm{f}} \quad=$ Calibration factor of capillary tube determined in accordance with BS 1881- 208 [31].

\section{Analysis and Discussion of Results}

\section{Initial Surface Absorption of Concrete at Equal Water/Cement Ratios}

Figures 3-5 present the ISA-10 of concretes at different water/cement ratios, curing ages and contents of SDA and laterite. The Figures show that
ISA-10 of concrete reduced with increasing curing age and increased with increasing water/cement ratio. The reduction in ISA-10 of concrete with increasing age must be due to refinement of pore structure by hydration products. This is because as hydration progresses, the pores would gradually be filled with hydration products and become reduced in size or discontinuous to reduce permeability [24 37 38]. On the other hand, the increase in ISA-10 with increasing water/cement ratio must be due to reduction in the content of the cementitious materials with increasing water/cement ratio.

The comparison of the Figures also shows that ISA10 increased with increasing content of laterite. The increase in ISA-10 with increase in laterite content would be due to the clay content of laterite resulting in higher content of fine particles and minute pores and higher absorption values [39]. It is also worth mentioning that the stickiness of clay content of laterite could also impair the thorough coating of the fine aggregates with cement and prevent the concretes from developing dense microstructure. The Figures also show that ISA-10 of concrete increased with increase in the content of SDA. The increase in ISA-10 with increase in the content of SDA would be due to the reduction in the content of Portland cement and therefore $\mathrm{Ca}(\mathrm{OH})_{2}$ required for the pozzolanic reaction of SDA; thus resulting in the production of insufficient hydration products and development of less dense microstructure.

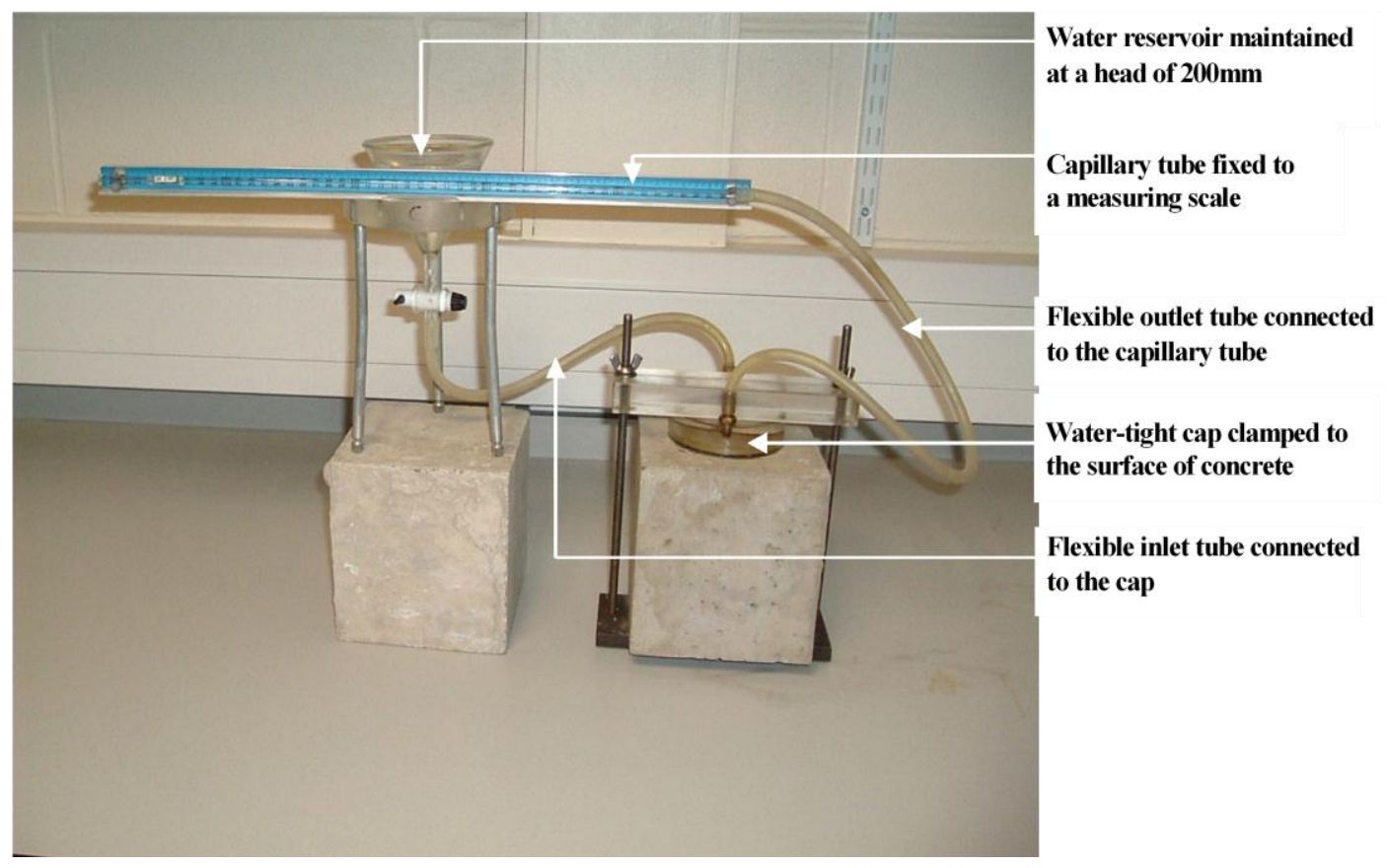

Figure 2. ISAT installation 

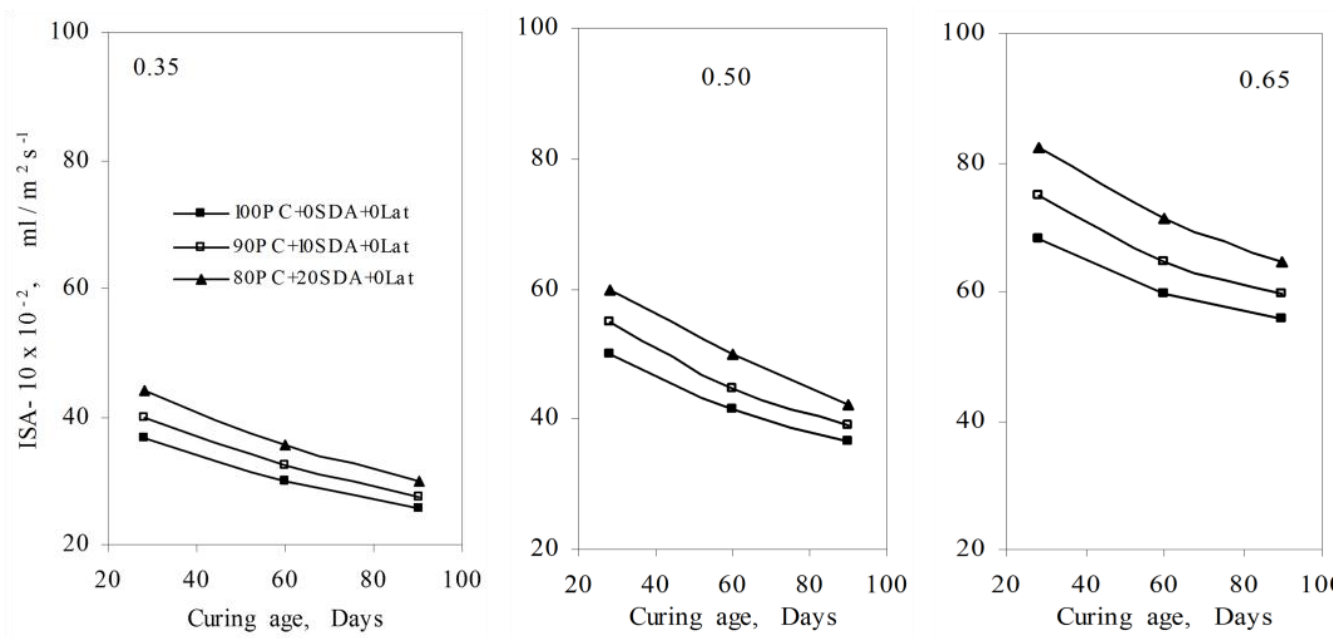

Figure 3. ISA-10 of Concretes at 0\% Content of Laterite
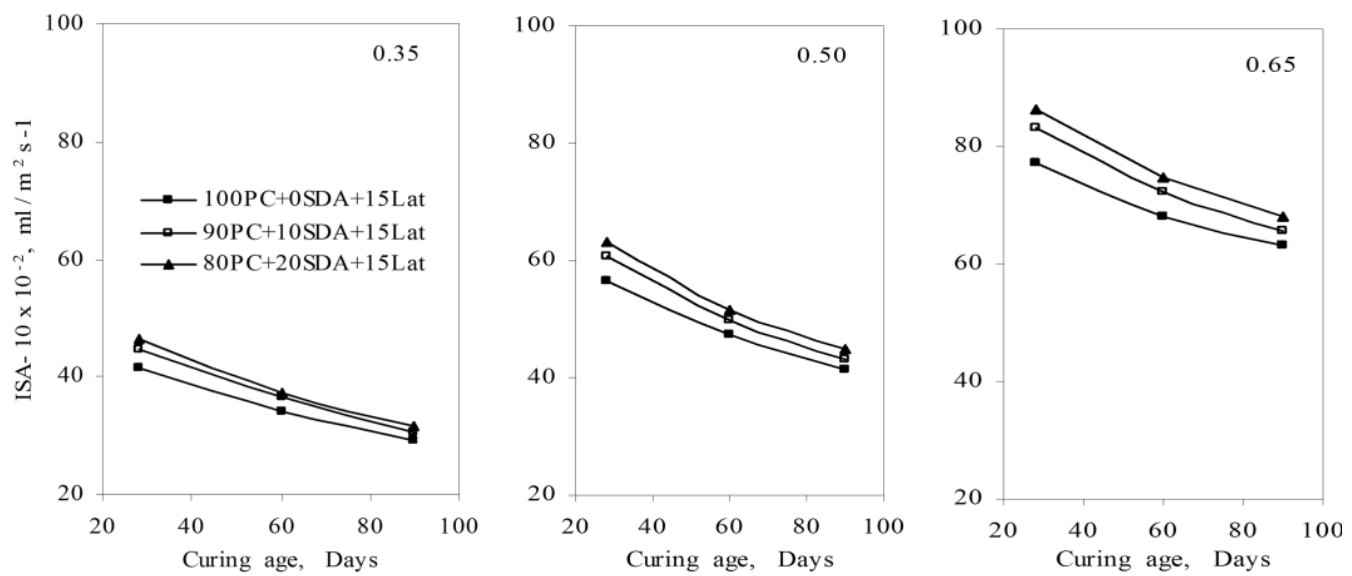

Figure 4. ISA-10 of Concretes at 15\% Content of Laterite
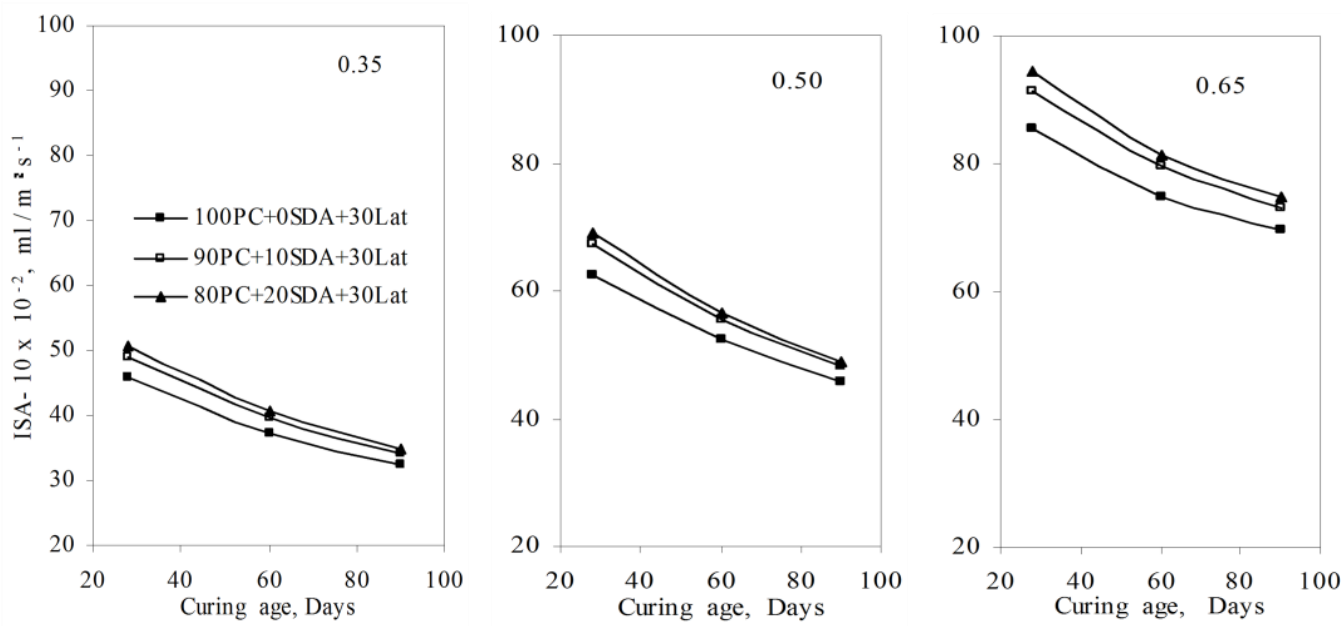

Figure 5. ISA-10 of Concretes at 30\% Content of Laterite

The ISA-10 factors (Table 3) measure the differences between the ISA-10 of the $100 \% \mathrm{PC}$ concretes and the laterized concretes at different ages and water/ cement ratios. The comparison of mixes 1,4 and 7 shows that the partial replacement of sand with $15 \%$ and $30 \%$ laterite respectively increased ISA-10 of 
laterized concrete by $13.59 \%$ and $25.39 \%$. Hence, ISA- 10 increased by $0.85-0.91 \%$ (with an average of $0.88 \%$ ) with a percentage replacement of sand with laterite. Hence, the increase in ISA-10 and therefore reduction in resistance to permeation would become significant with increasing content of laterite at equal water/cement ratios. The differences between the ISA-10 values of the conventional concretes (mix 1 ) and the SDA blended cement laterized concretes (mixes 2, 3, 5, 6, 8, and 9) reduced with increasing curing age. This reduction would be attributed to the pozzolanic reaction of SDA which improves with increasing curing age. This result is in line with previous study by Khan and Lynsdale [40] which shows that the incorporation of supplementary cementitious materials is capable of increasing the resistance of concrete at later ages against permeation.

Compared with the conventional concretes $(0 \%$ laterite), Table 3 shows that the partial replacement of PC with 10 and 20\% SDA resulted in ISA-10 increases of 8.25 and $18.75 \%$, respectively. This corresponds, respectively, to an ISA-10 increase of 0.83 and $0.94 \%$ (with an average of $0.89 \%$ ) for a percentage replacement of $\mathrm{PC}$ with SDA. Compared with concretes with $100 \% \mathrm{PC}$ and $15 \%$ laterite, the ISA-10 increases were 6.96 and 11.16 at the partial replacement levels of 10 and $20 \%$ respectively; thus resulting in ISA-10 increases of 0.70 and $0.56 \%$ respectively (with an average of $0.63 \%$ ) for a percentage replacement of PC with SDA. Similarly, at $30 \%$ laterite content, ISA-10 increased by 7.81 and $11.08 \%$ at the partial replacement levels of 10 and $20 \%$ SDA respectively. This also resulted in ISA-10 increase of 0.78 and $0.55 \%$ respectively (with an average of $0.67 \%$ ) for a percentage replacement of PC with SDA. Based on the foregoing, a percentage replacement of PC with SDA resulted in an ISA-10 increase of $0.89 \%$ for conventional concrete and 0.63 $0.67 \%$ (with an average of $0.65 \%$ ) for laterized concrete. These results show that the inclusion of laterite resulted in improved resistance of concrete to surface permeation. Hence, the synergy between laterite and SDA must have improved the resistance of concrete to permeation. Hence, the higher fineness and packing ability of laterite and pozzolanic reaction of SDA must have resulted in the improved resistance of the concrete to surface absorption.

Table 3. ISA-10 factors of concretes

\begin{tabular}{|c|c|c|c|c|c|c|c|c|}
\hline \multirow[b]{2}{*}{ Mix } & \multirow[b]{2}{*}{ Mix combination } & \multirow{2}{*}{$\mathrm{W} / \mathrm{C}$} & \multicolumn{5}{|c|}{ ISA-10 factor ${ }^{a)}, \quad(\%)$} & \multirow[b]{2}{*}{$\begin{array}{l}\% \text { Increase in } \\
\text { ISA-10 factor b) }\end{array}$} \\
\hline & & & $28 \mathrm{~d}$ & $60 d$ & $90 \mathrm{~d}$ & Mean & $\begin{array}{c}\text { Over-all } \\
\text { Mean }\end{array}$ & \\
\hline \multirow{3}{*}{1.} & \multirow{3}{*}{ 100PC+0SDA+0Lat } & 0.35 & 100 & 100 & 100 & 100 & & \\
\hline & & 0.50 & 100 & 100 & 100 & 100 & 100.00 & \\
\hline & & 0.65 & 100 & 100 & 100 & 100 & & \\
\hline \multirow{3}{*}{2.} & \multirow{3}{*}{ 90PC+10SDA+0Lat } & 0.35 & 109.04 & 108.36 & 106.62 & 108.01 & & \\
\hline & & 0.50 & 110.04 & 107.95 & 106.85 & 108.28 & 108.26 & 8.26 \\
\hline & & 0.65 & 109.69 & 108.19 & 107.55 & 108.48 & & \\
\hline \multirow{3}{*}{3.} & \multirow{3}{*}{ 80PC+20SDA+0Lat } & 0.35 & 120.55 & 119.36 & 116.39 & 118.77 & & \\
\hline & & 0.50 & 120.08 & 120.00 & 115.89 & 118.66 & 118.75 & 18.75 \\
\hline & & 0.65 & 120.71 & 119.40 & 116.37 & 118.83 & & \\
\hline \multirow{3}{*}{4.} & \multirow{3}{*}{ 100PC+0SDA+15Lat } & 0.35 & 113.70 & 113.71 & 113.23 & 113.55 & & \\
\hline & & 0.50 & 113.25 & 113.98 & 113.70 & 113.64 & 113.59 & 13.59 \\
\hline & & 0.65 & 113.36 & 113.88 & 113.49 & 113.58 & & \\
\hline \multirow{3}{*}{5.} & \multirow{3}{*}{$90 \mathrm{PC}+10 \mathrm{SDA}+15 \mathrm{Lat}$} & 0.35 & 122.74 & 122.07 & 119.46 & 121.42 & & \\
\hline & & 0.50 & 121.69 & 120.00 & 118.36 & 120.02 & 120.55 & 20.55 \\
\hline & & 0.65 & 121.88 & 120.74 & 117.99 & 120.20 & & \\
\hline \multirow{3}{*}{6.} & \multirow{3}{*}{$80 \mathrm{PC}+20 \mathrm{SDA}+15 \mathrm{Lat}$} & 0.35 & 127.40 & 125.08 & 122.57 & 125.02 & & \\
\hline & & 0.50 & 126.71 & 124.10 & 122.74 & 124.52 & 124.75 & 24.75 \\
\hline & & 0.65 & 126.73 & 124.92 & 122.48 & 124.71 & & \\
\hline \multirow{3}{*}{7.} & \multirow{3}{*}{ 100PC+0SDA+30Lat } & 0.35 & 125.21 & 125.08 & 126.07 & 125.45 & & \\
\hline & & 0.50 & 125.10 & 126.02 & 125.21 & 125.44 & 125.39 & 25.39 \\
\hline & & 0.65 & 125.55 & 124.92 & 125.36 & 125.28 & & \\
\hline \multirow{3}{*}{8.} & \multirow{3}{*}{$90 \mathrm{PC}+10 \mathrm{SDA}+30 \mathrm{Lat}$} & 0.35 & 134.25 & 133.11 & 132.30 & 133.22 & & \\
\hline & & 0.50 & 134.94 & 133.98 & 131.78 & 133.57 & 133.20 & 33.20 \\
\hline & & 0.65 & 134.07 & 133.28 & 131.06 & 132.80 & & \\
\hline \multirow{3}{*}{9.} & \multirow{3}{*}{$80 \mathrm{PC}+20 \mathrm{SDA}+30 \mathrm{Lat}$} & 0.35 & 138.63 & 136.12 & 135.80 & 136.85 & & \\
\hline & & 0.50 & 138.35 & 135.90 & 134.25 & 136.17 & 136.47 & 36.47 \\
\hline & & 0.65 & 138.91 & 135.95 & 134.35 & 136.40 & & \\
\hline
\end{tabular}

a) ISA-10 ratio with respect to the conventional concrete (mix 1)

b) \% Increase in ISA-10 factors with respect to the conventional concrete 


\section{Initial Surface Absorption at Equal Strengths of Concrete}

Structural concrete is usually specified on the basis of the 28-day strengths. In line with Folagbade [5], Table 4 shows that compressive strength reduced with increasing content of laterite and SDA. Hence, based on the interpolated values of the 28-day ISA10 values in Table 3 and the 28-day compressive strengths in Table 4, Table 5 presents the ISA-10 values of the conventional, laterized and SDA blended cement laterized concrete options at equal 28-day strengths, ranging between 20 and 35 $\mathrm{N} / \mathrm{mm}^{2}$, and the water/cement ratios at which the strengths were achieved. Table 5 shows that the laterized and SDA blended cement laterized concretes achieved equal strengths with conventional concrete at lower water/cement ratios. This would require higher contents of the cementitious materials [41]. Hence, where the cost and the embodied carbon dioxide content of SDA are low such that the cost and embodied carbon dioxide content of Portland cement is offset by the costs and embodied carbon dioxide contents of the cement combinations, cheaper and more environmentally compatible blended cement laterized concretes will result at equal strengths.

Table 5 shows that ISA-10 reduced with increasing strength. The observation of Isa-10 values at the 28day compressive strength of $30 \mathrm{~N} / \mathrm{mm}^{2}$ shows a minimum percentage reduction of $12.56 \%$ for mix 2 and a maximum percentage reduction of $24.17 \%$ for mix 3. Hence, within the limit of this study, all the laterized and SDA laterized concretes, at up to $30 \%$ contents of laterite and $20 \%$ contents of SDA, have lower ISA-10 values and therefore higher resistance to surface absorption than the conventional concrete when concrete is specified on the basis of strength.

\section{Conclusion}

This study investigated the compressive strength and initial surface absorption of concrete containing laterite as partial replacement for sand and SDA as partial replacement for PC and the following conclusions have been drawn:

- The 28-day compressive strength reduced with increasing water/cement ratio while the initial surface absorption reduced with increasing curing age and increasing compressive strength, and increased with increasing water/cement ratio.

- At equal water/cement ratios, compressive strength reduced and initial surface absorption increased with increasing laterite and SDA contents. However, the synergy between SDA and laterite resulted in improved resistance of concrete to surface absorption especially at later ages.

- With a percentage reduction of $12.56-24.17 \%$ in ISA-10 values at equal 28-day compressive

Table 4. 28-Day Compressive Strengths of Concretes

\begin{tabular}{ccccc}
\hline \multirow{2}{*}{ Mix } & \multirow{2}{*}{ Mix combination } & \multicolumn{2}{c}{ 28-Day Compressive Strength, N/mm ${ }^{2}$} \\
\cline { 3 - 4 } & & w/c $=0.35$ & w/c $=0.50$ & w/c $=0.65$ \\
\hline 1. & 100PC+0SDA+0Lat & 38.0 & 32.5 & 29.5 \\
2. & 90PC+10SDA+0Lat & 35.5 & 30.0 & 27.0 \\
3. & 80PC+20SDA+0Lat & 32.0 & 26.5 & 24.0 \\
4. & 100PC+0SDA+15Lat & 36.5 & 29.5 & 26.5 \\
5. & 90PC+10SDA+15Lat & 32.0 & 26.0 & 23.0 \\
6. & 80PC+20SDA+15Lat & 28.5 & 23.0 & 19.5 \\
7. & 100PC+0SDA+30Lat & 31.0 & 27.5 & 25.5 \\
8. & 90PC+10SDA+30Lat & 27.5 & 24.0 & 22.5 \\
9. & 80PC+20SDA+30Lat & 24.5 & 21.0 & 19.5 \\
\hline
\end{tabular}

Table 5. ISA-10 of Concretes at Different 28-Day Compressive Strengths

\begin{tabular}{|c|c|c|c|c|c|c|c|}
\hline \multirow{3}{*}{ Mix } & \multirow{3}{*}{ Mix combination } & \multicolumn{6}{|c|}{ ISA-10 of concrete $\times 10^{-2}, \mathrm{ml} / \mathrm{m}^{2} \mathrm{~s}^{-1}$} \\
\hline & & \multicolumn{2}{|c|}{$25 \mathrm{~N} / \mathrm{mm}^{2}$} & \multicolumn{2}{|c|}{$30 \mathrm{~N} / \mathrm{mm}^{2}$} & \multicolumn{2}{|c|}{$35 \mathrm{~N} / \mathrm{mm}^{2}$} \\
\hline & & w/c & ISA & $\mathrm{w} / \mathrm{c}$ & ISA & w/c & ISA \\
\hline 1. & 100PC+0SDA+0Lat & $*$ & $*$ & 0.61 & 62.73 & 0.42 & 42.08 \\
\hline 2. & 90PC+10SDA+0Lat & * & $*$ & 0.50 & 54.80 & 0.36 & 40.65 \\
\hline 3. & 80PC+20SDA+0Lat & 0.56 & 67.97 & 0.39 & 47.57 & * & $*$ \\
\hline 4. & 100PC+0SDA+15Lat & $*$ & * & 0.48 & 54.07 & 0.37 & 43.15 \\
\hline 5. & 90PC+10SDA+15Lat & 0.53 & 64.55 & 0.39 & 48.37 & * & * \\
\hline 6. & 80PC+20SDA+15Lat & 0.44 & 55.67 & $*$ & * & * & * \\
\hline 7. & 100PC+0SDA+30Lat & $*$ & * & 0.38 & 48.49 & * & $*$ \\
\hline 8. & $90 \mathrm{PC}+10 \mathrm{SDA}+30 \mathrm{Lat}$ & 0.44 & 59.21 & $*$ & * & $*$ & $*$ \\
\hline 9. & $80 \mathrm{PC}+20 \mathrm{SDA}+30 \mathrm{Lat}$ & $*$ & $*$ & $*$ & * & * & * \\
\hline
\end{tabular}

* Water/Cement ratio higher or lower than the range investigated 
strength of $30 \mathrm{~N} / \mathrm{mm}^{2}$, all the laterised and SDA laterised concretes at up to $30 \%$ laterite content and $20 \%$ SDA content would have higher resistance to surface absorption than the conventional concrete when concrete is specified on the basis of the 28-day compressive strengths.

Hence, if appropriately designed, the use of laterite and SDA as partial replacement for sand and PC respectively would result in concrete with better resistance in permeation than the conventional PC concrete.

\section{References}

1. Adepegba, D., A Comparative Study of Normal Concrete with Concrete which Contained Laterite Instead of Sand, Building Science, 10(2), 1975, pp. 135-141.

2. Adepegba, D., The Effect of Water Content on the Compressive Strength of Laterized Concrete, Journal of Testing and Evaluation, 3(6), 1975, pp. 449-453.

3. Falade, F., Influence of Water/Cement Ratios and Mix Proportions on Workability and Characteristic Strength of Concrete Containing Laterite Fine Aggregate, Building and Environment, 29(2), 1994, pp. 237-240.

4. Udoeyo, F.F., Iron, U.H., and Odim, O.O., Strength Performance of Laterized Concrete, Construction and Building Materials, 20(10), 2006, pp. 1057-1062.

5. Folagbade, S.O., Effect of Sawdust Ash on the Compressive Strength and Sorptivity of Laterised Concrete, Civil and Environmental Research, 10(10), 2018, pp. 5-14.

6. Lasisi, F. and Osunade, J.A., Factors Affecting the Strength and Creep Properties of Laterized Concrete, Building and Environment, 20(2), 1985, pp. 133-138.

7. Salau, M.A. and Balogun, L.A., Shear Resistance of Reinforced Laterized Concrete Beams Without Shear Reinforcement, Building and Environment, 25(1), 1990, pp. 71-76.

8. Ambrose, E.E., Ekpo, D.U., Umoren, I. M. and Ekwere, U.S., Compressive Strength and Workability of Laterized Quarry Sand Concrete, Nigerian Journal of Technology, 37(3), 2018, pp. 605-610.

9. Osunade, J.A., Effect of Replacement of Lateritic Soils with Granite Fines on the Compressive and Tensile Strengths of Laterized Concrete, Building and Environment, 37(5), 2002, pp. 491496.

10. Ukpata, J.O. and Ephraim, M.E., Flexural and Tensile Strength Properties of Concrete using Lateritic Sand and Quarry Dust as Fine Aggregate, ARPN Journal of Engineering and Applied Sciences, 7(3), 2012, pp. 324-331.
11. Onipe, M.O. and Folagbade, S.O., Void Content and Sorptivity of Laterized Concrete, in Aluko B. T., Odeyinka H. A., Amole O.O., Babasehinde A. A. and Daramola O.P. (Eds.), Proceedings of the Environmental Design and Management International Conference on Advances in Built Environment Research-Recent Advances and Future Directions, Faculty of Environmental Design and Management, Obafemi Awolowo University, Ile-Ife, Nigeria, 2017, pp. 159-168.

12. Lanre, O. and Asce, M., The Influence of Weather on the Performance of Laterized Concrete, Journal of Engineering and Applied Sciences, 2(1), 2007, pp. 129-135.

13. Olusola, K.O. and Joshua, O., Effect of Nitric Acid Concentration on the Compressive Strength of Laterized Concrete, Civil and Environmental Research, 2(10), 2012, pp. 48-58.

14. Ige, O.A., Performance of Lateritic Concrete under Environmental Harsh Condition, International Journal of Research in Engineering and Technology, 2(8), 2013, pp. 144-149.

15. Olusola, K.O. and Ata, O., Durability of Laterized Concrete Exposed to Sulphate Attack Under Drying-Wetting Cycles, Civil and Environmental Research, 6(3), 2014, pp. 33-38.

16. Salau, M.A. and Balogun, L.A., Shrinkage Deformations of Laterized Concrete, Building and Environment, 34, 1999, pp. 165-173.

17. BS EN 197- 1: 2000, Cement- Part 1: Composition, Specifications and Conformity Criteria for Common Cements, British Standards Institution, London.

18. BS EN 206-1: 2000, Concrete- Part 1: Specification, Performance, Production and Conformity, British Standards Institution, London.

19. Ogunbode, E.B., Ibrahim, S.M., Kure, M.A. and Saka, R., Flexural Performance of Laterized Concrete Made With Blended Fly Ash Cement (Fa-Latcon), Greener Journal of Science, Engineering and Technological Research, 3(4), 2013, pp. 102-109.

20. Ogunbode, E.B., Akanmu, W.P., Moses, D.W., Akaleme, M C. and Idris, H., Performance of Fly Ash Blended Cement Laterized Concrete in Sulphate Environment, International Journal of Emerging Trends in Engineering and Development, 2(3), 2013, pp. 186-197.

21. Ogunbode, E.B. and Akanmu, W.P., Turning Waste to Wealth: Potential of Laterized Concrete using Cassava Peels Ash (CPA) Blended Cement, International Journal of Engineering Research \& Technology, 1(3), 2012, pp. 1-12.

22. Olawuyi, B.J. and Olusola, K.O., Compressive Strength of Volcanic Ash/Ordinary Portland Cement Laterized Concrete, Civil Engineering Dimension, 12(1), 2010, pp. 23-28.

23. Olawuyi, B.J., Olusola, K.O., and Babafemi, A. J., Influence of Curing Age and Mix Composition 
on Compressive Strength of Volcanic Ash Blended Cement Laterized Concrete, Civil Engineering Dimension, 14(2), 2012, pp. 84-91.

24. Neville, A.M., Properties of Concrete, $5^{\text {th }}$ Edition, Prentice-Hall, London, 2012.

25. Falade F., Effect of Sawdust Ash on the Strength of Laterized Concrete, West Indian Journal of Engineering, 15(1), 1990, pp. 71-84.

26. Udoeyo, F.F. and Dashibil, P.U., Sawdust Ash as a Concrete Material, Journal of Materials in Civil Engineering, 14(2), 2002, pp. 173-176.

27. Elinwa, A.U. and Mahmood, Y.A., Ash from Timber Waste as Cement Replacement Material, Cement and Concrete Composites, 24(2), 2002, pp. 219-222.

28. Elinwa, A.U. and Ejeh, S.P., Effects of Incorporation of Sawdust Waste Incineration Fly Ash (SWIFA) in Cement Pastes and Mortars, Journal of Asian Architecture and Building Engineering, 3(1), 2004, pp. 1-7.

29. Raheem, A.A., Adedokun, S.I., Ajayi, B.R., Adedoyin, O.A., and Adegboyega, B.O., Application of Saw Dust as Partial Replacement for Cement in the Production of Interlocking Paving Stones, International Journal of Sustainable Construction Engineering and Technology, 8(1), 2017, pp. $1-11$.

30. Udoeyo, F.F., Inyang, H., Young, D.T., and Oparadu, E. E., Potential of Wood Ash as an Additive in Concrete, Journal of Materials in Civil Engineering, 18(4), 2006, pp. 605-611.

31. BS 1881- 208: 1996, Testing Concrete- Part 208: Recommendations for the Determination of the Initial Surface Absorption of Concrete, British Standards Institution, London.

32. Teychenne, D.C., Franklin, R.E., and Erntroy, H.C., Design of Normal Concrete Mixes, $2^{\text {nd }}$ Ed., amended by B.K. Marsh, Building Research Establishment, Garston, England, 1997.
33. BS EN 934-2: 2009, Admixtures for Concrete, Mortar and Grout- Part 2: Concrete AdmixturesDefinitions, Requirements, Conformity, Marking and Labelling, British Standards Institution, London.

34. BS EN 12390-2: 2000, Testing Hardened Concrete- Part 2: Making and Curing Specimens for Strength Tests, British Standards Institution, London.

35. BS EN 1008: 2002, Mixing Water for ConcreteSpecification for Sampling, Testing and Assessing the Suitability of Water, Including Water Recovered from Processes in the Concrete Industry, as Mixing Water for Concrete, British Standards Institution, London.

36. BS EN 12390-3: 2002, Testing Hardened Concrete- Part 3: Compressive Strength of Test Specimens, British Standards Institution, London.

37. Mehta, P. K. and Monteiro, P., Concrete: Microstructure, Properties and Materials, McGraw Hill, New York, NY, 1997.

38. Korpa, A., Kowald, T., and Trettin, R., Hydration Behaviour, Structure and Morphology Phases in Advanced Cement-Based Systems Containing Micro and Nanoscale Pozzolanic Additives, Cement and Concrete Research, 38(7), 2008, pp. 955-962.

39. Kelham, S.A., A Water Absorption Test for Concrete, Magazine of Concrete Research, 40(143), 1988, pp. 106-110.

40. Khan, M.I. and Lynsdale, C.J., Strength, Permeability and Carbonation of High-Performance Concrete, Cement and Concrete Research, 32(1), 2002, pp. 123-131.

41. Folagbade, S.O. and Newlands, M.D., Suitability of Cement Combinations for Carbonation Resistance of Structural Concrete, Journal of Engineering, Design and Technology, 12(4), 2014, 423-439. 